Forum

\title{
Who Put Hate in My Sunday Paper?
}

\author{
Omid Safi
}

\section{Uncovering the Israeli-Republican-Evangelical Networks behind the "Obsession" DVD}

Something strange showed up inside the Sunday newspapers of millions of Americans last September. The material included alongside comics, coupons, and advertisement for local stores is a controversial DVD called "Obsession: Radical Islam's War against the West." Some 28 million copies of it were distributed for free in this fashion. In some ways, this campaign's scale and ideological venom were unprecedented: many newspapers stated that they had never previously distributed free DVDs as inserts, certainly nothing with such a charged content. The copies were distributed not randomly across the country, but only in the "swing states" (viz., Florida, Pennsylvania, Ohio, Michigan, Wisconsin, Iowa, Colorado, etc.) that were seen as toss-ups in the November presidential elections between McCain and Obama. Obviously, someone was trying to influence the American electorate by playing on fearmongering and hate-mongering themes. But who? Who was behind this massive, multi-million dollar campaign?

Answering that question proved harder than one might think, as the groups behind this DVD have worked hard to hide their tracks. The connections, which were partially concealed in the DVD and the distribution campaign, took one from groups in Israel to pro-Israel lobby organizations in the

Omid Safi is associate professor of Islamic studies at the University of North Carolina, Chapel Hill, where he specializes in Sufism, contemporary Islamic thought, and medieval Islamic history. The author of several books, he is also chair for the Study of Islam at the American Academy of Religion and a member of the advisory board for Harvard's Pluralism Project. The opinions here are the author's personal views and do not reflect those of the University of North Carolina or of the American Academy of Religion. This article originally appeared on the author's blog: http://omidsafi.com. We thank him for allowing us to publish a slightly copyedited version of it here. 
United States, to Christian evangelical groups, and to neo-conservative think tanks.

The "facts" presented by "Obsession" have already been refuted in several detailed presentations. For example, see the work of www.Obsessionwithhate.com and that of Sheila Musaji, as well as www.Altmuslim.com. Therefore, I am not going to make a point-by-point refutation of them. My intention is to explore the networks behind the DVD's production and distribution, with their clear goal of influencing the 2008 presidential elections toward John McCain.

****

All politics is local as well as global. This is particularly the case here. The DVD's distribution affected me and my family on an intimate local level: up to 160,000 copies were distributed through our local community in North Carolina. The newspaper of the nearby city of Charlotte distributed another 200,000 copies.

Upon contacting the local newspaper, the Raleigh-based News and Observer, and asking why such a hateful piece of propaganda was being distributed for free to all of its subscribers, the paper's response was less than impressive. Jim McClure, vice president of display advertising, said: "Obviously, we have distributed other product samples, whether it's cereal or toothpaste."

Really? Is this where we are? That a DVD which includes seventyseven minutes of propaganda footage slicing together videos of violent Muslims with those of Nazis, suggesting that Muslims are out to destroy western civilization, is comparable to cereal and toothpaste? Puhleeze ...

The claims of the DVD, which claims to be an educational product and part of a non-profit production, are as follows:

- That the world stands today as it did in 1938. Radical Islam is as great, if not greater, of a threat than the Nazis presented to the world. And action [not specified] must be taken.

- That the attacks in Iraq, Palestine, Chechnya, and Iran present a global Muslim conspiracy against Israel and "the West."

- A distinctive feature of the DVD is in fact the linking together of the threat of radical Islam with a passionate defense of Israel. Most of the figures paraded in the DVD, whether they are Jewish, Christian, or 
Muslim, are all passionate pro-Israel speakers who have a long history of speaking against Palestinians, Arabs, and Muslims in general. The list includes such luminaries as:

- "Former PLO Terrorist Who Speaks Out For Israel," Walid Shoebat, who claims to have been a "former Islamic terrorist" turned Christian Evangelical Zionist. Never mind that the Jerusalem Post has already dismissed the factuality of his claims.

- Nonie Darwish, with the tell-all website: www.arabsforisrael.com. Darwish also neglects to mention that she is another ex-Muslim turned both Christian and ardent supporter of Israel. In a world where virtually all Arabs and most Muslims view the Palestinian/ Israeli tragedy as the burning political and moral issue of our time, how many Arabs can claim to be passionate supporters of Israel?

- Carline Glick, a member of the Israel on Campus Coalition.

- Daniel Pipes. If the pro-Israel/neo-conservative unholy alliance had a poster child, Pipes would be it. The most noted Islamophobe operating in the United States, he is also the director of a pro-Israel entity called "The Middle East Forum." As for his one-sided commitment to Israel's credentials, suffice it to say that he was the 2006 recipient of the "Guardian of Zion" award.

One could go on and on, but the above should give some indication that contrary to what the Clarion Fund claims on its website, the "experts" paraded on television are neither impartial nor objective. They have a definite point of view: a passionate defense of Israel at all costs, even if that cost happens to be at the expense of the truth and the facts.

\section{Who Made This DVD?}

Let's come back to the local newspaper's claim, that distributing this product is qualitatively no different than putting a free sample of toothpaste in the Sunday paper. For the sake of argument, let's accept that analogy and go with it. How many of us would receive an unmarked package of toothpaste and brush our teeth with it if it carried no label, no description of who made it, and no account of whether any agency has vouched for its safety? If we do not apply unmarked material to our teeth, why would we take a product like "Obsession," which refuses to disclose the network behind it, into our hearts, schools, synagogues, mosques, churches, and civic institutions? 
The DVD states that it is made by the "Clarion Fund." What does the Clarion Fund stand for, and who exactly are they? Their intentions are made a bit clearer through the use of their registered website: www.radicalislam.org. What exactly does "radical Islam" constitute? Who stands for it, and who opposes it? We are not told, aside from this: "Radical Islam poses a significant threat to the Western way of life. The Islamists' ultimate aim is conversion and domination of the West, which they see as the root of all evil that must be eradicated." This type of labeling without defining is as unhelpful as accusations of "communist" in the 1950s, or "unpatriotic" and "unAmerican" more recently. It is a catch-all bogeyman argument masquerading as analysis.

Who produced the DVD? On the "Obsession: The Movie" website, the producer is identified as Raphael Shore, "a documentary producer and founder of Clarion Fund, Inc., a new non-profit organization dedicated to educating the public about national security threats." Very well. So Raphael Shore is the founder and producer. But who is Raphael Shore? This required a good bit of background research.

\title{
Raphael Shore and Aish HaTorah
}

Raphael Shore is part of a missionary Israeli "Jewish penitent" (baal teshuva) group called Aish HaTorah (Fire of the Torah), whose mission is to call "assimilated" Jews back to Judaism. The Israeli government has given this group 40 percent of the land in front of the "Western Wall" in Jerusalem. In other words, they are on very good terms with the Israeli regime, which is responsible for demolishing homes, denying building permits, and occupying in Palestine. Their founder, Rabbi Noah Weinberg, has received recognition from the mayor of Jerusalem.

When we dig a bit deeper, it turns out that Raphael Shore, a Canadian rabbi, is also the director of the International wing of Aish HaTorah. His business card is available as a PDF online:

\author{
Rabbi Raphael Shore \\ Director, Aish HaTorah International \\ Outreach Programs \\ One Western Wall Plaza \\ Old City, Jerusalem \\ Israel, 97500
}

So does "Obsession" fall within the purview of Aish HaTorah's "outreach"? Given the intertwined nature of the political and the religious in 
Israel, it seems that Aish HaTorah has gone from evangelizing Jews to waging a global propaganda campaign against Islam and Muslims, while also working hard to cover its tracks, as we shall see.

The connection between Aish HaTorah and the Clarion Fund goes even deeper. According to the paperwork filed with the Delaware state authorities, Clarion uses the same address as Aish HaTorah in New York. In 2006, the two directors of the Clarion Fund were Rabbi Shore and Jacob Fetman (also Aish HaTorah's chief financial officer). In 2007, it had three directors: Rabbi Shore, Rabbi Harris (educational director, Aish HaTorah), and Rebecca Kabat, another Aish HaTorah employee.

The Israeli paper Haaretz noted that the DVD "has a largely Jewish and pro-Israel distribution network, though Shore is trying to expand the film's appeal." As we shall see, he accomplished this by reaching out to neoconservatives and Christian Zionists. But first, some more on the film's proIsrael distribution network.

\section{Hasbara Fellowship and www.Honestreporting.com}

Raphael Shore is also the director of Hasbara Fellowships, a group with the transparent website www.israelactivism.com. Here is another connection to Aish HaTorah, as Hasbara is part of the Aish HaTorah network ... and their activism on behalf of Israel is worn like a badge of honor.

The pattern begins to become clearer: how is it that a group with the stated goal of "Israel activism" placed 28 million copies of a DVD warning Americans about the danger of "radical Islam"? In many of the screenings of this DVD, the audience was required to sign up for receiving material from the www.israelactivism.com website. How come seventy American newspapers accepted this DVD without doing the basic research to uncover the source (and prejudice) of this propaganda?

Hasbara Fellowship's own websites includes the following pieces of information about their genealogy and mission. All of the following are direct quotes:

- Hasbara Fellowships, a program spearheaded by Aish International, educates and trains university students to be effective pro-Israel activists on their campuses. [My comment: In other words, they freely acknowledge the link to Aish HoTorah International.]

- Started in 2001 in conjunction with Israel's Ministry of Foreign Affairs, Hasbara Fellowships brings hundreds of students to Israel every summer and winter. [My comment: This is perhaps the most intriguing con- 
nection and startling confession, that Hasbara has a direct connection to the Israeli regime's Ministry of Foreign Affairs, which acts as the official and national propaganda center for the Israeli state. To recapitulate, there is a direct link between the "Obsession" DVD and the Israeli state through Hasbara Fellowship.]

- So far, Hasbara Fellowships has trained over 1,400 students on over 250 campuses, providing its participants with the information, tools, resources, and confidence to return to their campuses as leaders in the fight for Israel's image. [My comment: This points to the acknowledgement that the struggle over Palestine/Israel is going to be fought - rhetorically, one hopes - on college campuses. In fact, college campuses formed the primary site of the distribution of the "Obsession" DVD before the newspaper campaign. The primary audience on college campuses have been Jewish organizations (like Hillel) and College Republicans. We will come back to this connection between Jewish groups and Republicans later. Shore himself has stated that: "The evangelical Christians and the Jews tend to be the softest market..."]

Raphael Shore has previously written at length about his passionate advocacy on behalf of Israel on the pages of Aish HaTorah's newsletter. His earlier works were produced alongside "www.Honestreporting.com," which has the following self-description: "Israel is in the midst of a battle for public opinion - waged primarily via the media. To ensure that Israel is represented fairly and accurately, "Honest Reporting" monitors the media, exposes cases of bias, promotes balance, and effects change through education and action." In other words, www.Honestreporting.com sees itself as a media advocacy organization on behalf of Israel, with the requisite "fair and balanced" claims.

This organization has worked with the Clarion Fund and Aish HaTorah in producing more pro-Israel material. And it is a family affair: the founder of Honest Reporting is Rabbi Raphael Shore's twin brother Ephraim. [Ironically, Raphael was so concerned that his brother had become involved with Aish HaTorah that in 1992 he went to Israel to "rescue" his brother from what he seems to have regarded as a "big hoax," and a cult-like milieu. Instead, Raphael too became part of Aish HaTorah!]

Haaretz reported that "Obsession" is described as "Honest Reporting's newest documentary film." Its own website confirms this: "Honest Reporting is proud to have been a former marketing partner during the initial production of this award-winning documentary." 
Shore, recognizing that the credibility of his propaganda would be undermined if its connection to Israeli-spin organizations were revealed, told Haaretz (in an unusually frank slip) that they "have told Honest Reporting to take it off their site 'a dozen times." The connections between "Obsession" and Israeli groups like Aish HaTorah as well as between Jewish advocacy groups on behalf of Israel like Hasbara Fellowship and www.Honestreporting.com is beyond dispute. The producers of the documentary just do not want you to know about it.

One of the other elements that the "Obsession" producers may not want you to know about is their political agenda. The article read: "McCain's policies seek to confront radical Islamic extremism and terrorism and roll it back while [Barack] Obama's, although intending to do the same, could in fact make the situation facing the West even worse."

Clarion Fund spokesperson Gregory Ross did not deny that this article had appeared on their site; he was only upset that they had been caught with it! The Clarion Fund was established as a 501(c)3 non-profit organization. These types of non-profit organizations are not allowed to endorse one political candidate over another - precisely what Clarion seems to have done and is now busy hiding its track records. NPR reported on this, and the possibility of a forthcoming Federal Elections Commission (FEC) probe.

\section{Who is Paying for the "Obsession Project"?}

We do not know for sure, and the Clarion Fund people are not saying. They admit that the names they give for the funders on their material are bogus aliases. Shore states that 80 percent of the funding for "Obsession" comes from one source, a certain "Peter Mier." Yet he goes on to say that such names are just aliases! In other words, it is hard to know for sure who is paying for the production and, even more importantly, the distribution of what the Endowment for Middle East Truth (EMET), the main distributor for "Obsession," refers to as the "Obsession Project."

Given that EMET estimates that this project costs tens of millions of dollars, the signs seem to point to none other than Sheldon Adelson, the Jewish Republican billionaire, discussed below.

\section{Who Distributes the DVD?}

According the New York Times, when Shore and Co. could not find any traditional distributor for their propaganda, they formulated a strategy of working with neo-Conservative organizations like the Heritage Foundation, the College Republicans, and above all, Jewish organizations. 
NPR has reported that EMET is also responsible for distribution. Like www.Honestreporting.com, the "Middle East Truth" being bandied about here is yet another self-described Zionist/pro-Israel understanding of reality - the policies of which are in line with Likud's militant expansionism, with the stated mission of supporting Israel and opposing any "concessions" from Israel as part of a peace agreement with Palestinians, even the withdrawal from the occupied territory of Gaza. The positions of EMET are those of Israel's Likud party and of the illegal Settler movement. In fact, EMET sponsored a showing of "Obsession" on Capitol Hill on March 25, 2008.

EMET also has an open connection to the Republican Party, which they flaunt on their website: "EMET was also requested to help the Republican Policy Committee with a Sense of the Congress resolution talking about Israel's inherent right to defend itself..." In other words, the Clarion Fund claims to be non-political but uses a pro-Israel ally of the Republicans to distribute its product.

Leading the work of this endowment is Sarah Stern, who formerly worked as the national policy coordinator for the Zionist Organization of America and later on served as the director of the American Jewish Congress' (AJC) Office of Legislative and Governmental Affairs.

In short, the DVD's distributors are the most ardent and fanatical supporters of Israeli Likud militant expansionism, a fact that the DVD conveniently omits and that the newspapers who spread the 28 million copies of it like a virus never looked into. EMET also has a cozy relationship with the right-wing Jewish billionaire Sheldon G. Adelson, who has a proven track record of using his wealth to push both Israeli Likud-type and Republican agendas. Adelson has a long-standing and public relationship with the archLikud Netanyahu, which Haaretz has reported on previously. A recent investigative piece in the New Yorker provided many details of Adelson's political agenda in both the United States and Israel. Adelson, who owns many casinos in Las Vegas, has been a long-time contributor to the Zionist Organization of America, Sarah Stern's former employer. Now that Stern is at EMET, she has sponsored lecture series and seminars on Capital Hill in his name, to extend his influence into the Congress.

Adelson is usually listed as by Forbes as the third richest American and the sixth richest person in the world. His personal wealth is estimated as exceeding \$20 billion. The Washington Post reports that he has already given over \$200 million to Jewish and Israeli causes, including the Birthright program, to which he makes a $\$ 25$ million annual contribution.

To place Adelson on the political spectrum, it is good to recall that he has described himself as a critic of AIPAC - from the far right! In other words, 
he feels that AIPAC (the American Israel Public Affairs Committee) has been too soft on Palestinians. (!) Adelson has been a longtime contributor to Jewish and Republican causes, including the campaigns of George W. Bush. Initially, he had designs of spending $\$ 250$ million dollars to set up an organization called Freedom Watch to keep Obama out of the White House. Freedom Watch, conceived of as the Right's answer to www.Moveon.org, has been a meeting ground between Jewish Republicans and former officials of the George W. Bush administration. Such is the agenda of Adelson, the person whose influence is behind the EMET folks distributing "Obsession."

Who else serves on the board of EMET, the pro-Israeli lobby group? A who's who of Israeli officials and ultra-Zionists in the United States:

- Ambassador Yossi Ben-Aharon: Former chief-of Staff for Ytzak Shamir and Deputy Director General of the Ministry of Foreign Affairs.

- Ambassador Yoram Ettinger: "Minister for Congressional Affairs at Israel's Embassy in Washington (with a rank of an ambassador), Israel's Consul General in Houston and Director of Israel's Government Press Office."

- Lenny Ben-David: “Israel's Deputy Chief of Mission (number two diplomat) in Washington after being appointed by Prime Minister Benjamin Netanyahu," who in addition also has "held senior posts in the American Israel Public Affairs Committee for 25 years, in both Washington and Israel."

In addition to Israeli officials, the EMET board also includes:

- Neo-conservatives like R. James Woolsey, Frank Gaffney (another neocon who has received awards from the ZOA), Ariel Cohen (from the neo-conservative bastion Heritage), and David Dalin (from the neo-con Hoover Institute and also Heritage).

- Ardent pro-Israel lobbyists like Daniel Pipes, Caroline Glick (deputy managing editor of the Jerusalem Post), and Meyrav Wurmser (former director of the highly biased MEMRI, a propaganda organization founded by members of the Israeli Defense Force). Also serving on this board are many of the "talking head" would-be experts of "Obsession," such as Walid Shoebat.

- Christian Zionists: EMET also reaches out to Christians - or, one should specify, Christian Zionists - by featuring Rev. James. M. Hutchens, who founded an organization called The Jerusalem Connection International. 
There are many more connections to pro-Israel organizations responsible for the distribution of "Obsession":

- The producer, Raphael Shore, used Karyn Leffel from Hasbara Fellowship to establish links on college campuses. Yes, the same Hasbara of pro-Israel media advocacy.

- The producers also worked with the most lunatic fringes of the Christian evangelical movement to distribute their propaganda. This included, above all else, Christians United for Israel (CUFI), which mailed out many copies of the DVD from its mailing center. And CUFI's founder and national director? None other than the same pastor John Hagee from whom McCain had initially sought an endorsement, the same John Hagee who routinely describes Islam as evil and sees the restoration of Israel as a necessary step toward the return of Christ. Hagee is one of the leading Christian Zionists in America today, and those who know about the tortured history of this variety of Zionism know how easily it has veered toward anti-Semitism, even justifying Hitler as God's hunter to drive Jews out of Europe and to Israel, so that the Israeli state could be established (thus anticipating Christ's return).

- The Clarion Fund has also worked with other Republican groups to distribute its propaganda. NPR reported that a political consultant named Joe Wierzbicki was screening the film on 9/11 in Dearborn, MI. Who is paying for the screening and hiring Wierzbicki? Interestingly enough, Wierzbicki is the PAC coordinator for an organization called "Our Country Deserves Better," which had one specific goal: to defeat Barack Obama. Their website stated: "Our Country Deserves Better than Barack Obama - and with your help we can ensure that Barack Obama is defeated on November 4th."

The lines of connection between the makers of the allegedly impartial and non-profit "Obsession" and politically partial Republican groups and pro-Israeli expansionist Jewish organizations continues to grow...

- The latest verified connections so far is between the producers and the Republican Jewish Coalition (RJC). The RJC worked hand in hand with CUFI to mail out the "Standing with Israel" package to a large number of American rabbis and leaders of the Jewish community. The package also included a copy of "Obsession" and an approving letter from a former Israeli ambassador to Jews encouraging them to strengthen connections with Christian Zionists. 
The RJC is yet another group that the Clarion Fund and EMET has worked with that has taken a partisan political position on the forthcoming election. On its website, the RJC states that Barack Obama and Joe Biden and their supporters "have handed Ahmadenijad [sic] a big win."

\section{Islam or Radical Islam?}

Perhaps a word should be added here about the distinction between "Islam" and "radical Islam." In the last few years, we have indeed seen a number of terrorist acts around the world that have resulted in the death of thousands. While the bulk of these have not emanated from Islamic organizations, many have. (Of course, the majority of the victims of such acts even in these latter cases have been other Muslims.) No doubt, a critical look at the ideology of terrorist groups is more than called for in today's political climate. What many would object to, however, is painting all Muslims and all of Islam with the same brush.

"Obsession" opens by making a sharp distinction between "Islam" and "radical Islam." The producers of the documentary adamantly state that they are not anti-Islam or anti-Muslim, but that they are only against "radical Islam." Leaving aside for a moment the debates over what constitutes "radical Islam" and how pervasive it actually is, there is an uncomfortable disconnect between this claim on their website and the claims made inside the DVD: the people paraded as would-be experts do not, in fact, share this neat dichotomy between "Islam" and "radical Islam." The many speakers paraded here have a documented history of making blanket statements against Islam - all of Islam - and all Muslims.

Let's take one example, the very first speaker shown on camera: Walid Shoebat. Shoebat's claim to fame is that he purports to be an ex-"Islamic terrorist" turned Christian and lover of Zion. If he claims to have produced bombs to kill citizens, why is he not in prison? Muslims are routinely jailed for far less and indirect accusations. Nevertheless, let's examine Shoebat's track record regarding some of his more audacious claims about Islam (not just "radical Islam"):

- That Obama is a Muslim. Yes, that old myth again. Sadly, some 13 percent of American citizens believe this to the case, in spite of the fact that Obama is a committed Christian. Who knows how many more people are moved against Obama due to this rumor? 
- "The Arabic-speaking communities in America, however, do indeed support Osama bin Ladin and Hamas." [For some reason, Afghans and Iranians do not, he states.] Shoebat goes on to say: "The less they know about Islam the more peaceful they are." In other words, the Islamophobic assertions that peaceful Muslims are not peaceful because of Islam, but in spite of Islam; whereas "radical Muslims" are precisely radical and violent because of Islam. Something about that logic seems flawed, since it deprives human beings of the agency to actually interpret their own tradition in both beautiful and hideous ways.

- He has been even more forceful in asserting that Islam is evil. His exact words: "Islam is not the religion of God - Islam is the devil." Let us be explicit here: The "Obsession" DVD claims that it is not targeting Islam; it is targeting "radical Islam." The first person featured in the DVD sings a different tune, literally demonizing all of Islam.

- Shoebat's solution to Palestine/Israel, as told to the right-wing "Religious Zionist" Israel National News (the voice of the illegal Settler movement in the West Bank and Gaza) is as follows: tear down the Dome of the Rock and reestablish Solomon's Temple on the Temple Mount. The Settler radio embraced him as "the former terrorist turned lover of Zion." The question is whether this is the kind of person from whom one should take impartial advice. It makes as much sense as taking advice about Judaism or African-American history from David Duke, former Grand Wizard of the Knights of the Ku Klux Klan.

For one other example, we could look at another of the talking heads in the documentary, the Lebanese Christian Brigitte Gabriel, who appeared before the CUFI conference on 27 July 2007 (sponsored by Pastor Hagee) and opined:

The difference, my dear Christian friends, between Israel and the Arab world is quite simply the difference between civilization and barbarism. It's the difference between good and evil and this is what we're witnessing in the Arabic and Islamic world. I am angry. They have no SOUL! They are dead set on killing and destruction. And in the name of something they call "Allah," which is very different from the God we believe in, because our God is the God of love.

No fair-minded person would take Gabriel's hateful words as authoritative teachings of the Christian tradition or as exemplifying Christian 
love. And yet the producers of "Obsession" want the viewers to take her as an authoritative expert on Islam and Muslims. Somehow when Gabriel describes the whole "Islamic world" as having "no soul," I suspect that we are no longer in the realm of "we are not talking about Islam, we are talking about Islamic radicals" position behind which the producers hide. No wonder that the New York Times described her as a "radical Islamophobe."

Christ reminded us that by their fruits (and words) you shall know them. And the words of these hate-filled so-called experts speak for themselves.

\section{Conclusion}

The massive scale of the "Obsession" campaign raises a number of disturbing issues: it points to the ease with which foreign groups from Israel have established non-profit organizations in the United States to sway American elections by working with fringe elements from the pro-Israel lobby as well as from the Republican, and Evangelical communities. While their ideology is marginal, their wealth and influence is anything but marginal. Nonprofit organizations seeking to exert political influence are not illegal, but non-profits seeking to endorse political candidates and swaying elections are, and this is precisely what the network behind the "Obsession" DVD seeks to do.

The "Obsession Project" also points to journalism's eroding standards. Why has mainstream American journalism been so slow to pick up on these networks, all of which are publicly available, and do some investigating?

This project also points to the ever-increasingly poisonous political climate in our country, where demonizing an entire ethnic or religious community seems to be becoming more and more commonplace. We have seen African-Americans, Hispanics, Muslims, gays, lesbians, and others characterized in such a fashion. Perhaps no community in the West has been the victims of millennia-long persecution and "other"-ing campaigns as has the Jewish community. That makes it all the more devastating - and disappointing - that centrally situated and powerful Jewish organizations from both Israel and the United States are now deploying the same "other"-ing strategies against other minority groups, with hardly a voice of dissent being heard from other Jewish organizations. Indeed, "Obsession" is already tearing down bridges of dialogue between Muslim and Jewish groups across the country that had taken years to establish.

It is readily admitted that Israel remains both a rallying cry and a source of tension for many American Jewish organizations and American Jews. 
There are important fissures in the American Jewish community over all issues, including that of Israel. No one group speaks for all American Jews, who have often had an exemplary legacy of peace and justice activism. Indeed, one can point to many American Jews who have taken the lead in criticizing Israeli human rights violations against Palestinians. One important question that has yet to be answered is whether propaganda like "Obsession" will be met with silence by the Jewish community, or if it will be spoken against by all (Muslims, Jews, Christians, etc.) who are committed to peace and social justice.

Lastly, we do note from historical experience that campaigns like this tend to increasingly lower the bar of what is acceptable speech as opposed to "hate speech." Make no mistake about it: there will be follow up projects. The Clarion Fund has already declared that its next project is a documentary titled "Third Jihad." The synopsis is as follows: "How is radical Islam operating inside the West? Is a subversive 'cultural jihad' underway? How does radical Islam plan to bring America to its knees? What is the endgame?" According to www.richardsilverstein.com, the "Clarion Fund, producers of Third Jihad, have scored a mini-coup by snagging a deal to distribute their film online (for free) with Snag Films." In other words, if "Obsession" was about the danger of radical Islam "over there," "Third Jihad" will make the case that this same threat exists "over here." One shudders at the thought of the hate these pieces of propaganda are producing against members of the American Muslim community.

We can either keep going down this slippery slope of accusations and blanket generalizations, or we can bond together and rise up to say "Enough!" The point is not only that Muslims are being targeted, for it is the very poisoning of our cultural discourse and our hopes for a pluralistic American society that can welcome and embrace pluralism. To quote Martin Luther King Jr.: "Returning hate for hate multiplies hate, adding deeper darkness to a night already devoid of stars." What we need now is less of the hateful heat of "Obsession" (and its networks) and more light from all of us who are committed to a just and pluralistic future for all of us.

Toward that day, starting today.... 